\title{
Intercultural Differences in the Purchase and Information Behaviour of Young Consumers
}

\author{
Beno Klemenčič' ${ }^{1}$, Gabrijel Devetak ${ }^{2}$, Darko Števančec ${ }^{1}$ \\ ${ }^{1}$ Business School Murska Sobota, Noršinska ulica 13, 9000 Murska Sobota, Slovenia, beno.klemencic @ gmail.com; \\ Da01111@gmail.com \\ ${ }^{2}$ Faculty of Commercial and Business Sciences, Lava 7, 3000 Celje, Slovenia, mandrija@ siol.net
}

\begin{abstract}
Pressures in the contemporary marketing environment are getting bigger and companies and marketers are required to know consumers and their purchase and information behaviour. In this article we studied the behaviour of consumers and the factors of purchase and information behaviour of young consumers when choosing clothes. We found out about the meaning of individual clothing characteristics having impact on the purchase decision making (price, trademark, fitting of clothing, design, quality, etc.). Consumers receive and look for information at different sources (radio commercials, TV commercials and shows, fashion magazines, catalogue sales, social networks, friends and acquaintances, etc.). With the empiric research we wanted to find out to what measure individual sources influence the purchase decision of an individual. We studied young people aged from 15 to 24 in the countries of the EU (Slovenia, Austria and Germany) and the United States of America. We especially focused on characteristic differences. Knowing intercultural differences is important for global companies of the clothing industry for forming their marketing strategies. On the sample of 440 young people who took part in the survey we found out that intercultural differences exist regarding the influence of individual information sources and regarding the factors of purchase decision making. Considering the stated we propose companies operating in global markets on both continents to prepare differentiated marketing strategies.
\end{abstract}

Key words: consumer behaviour, clothing, marketing strategies, intercultural differences

\section{Introduction}

Consumer purchase behaviour can be defined as behaviour that is demonstrated by consumers when looking for, assessing, purchasing, using and abandoning products and services for which it is expected that they will satisfy the consumer's wishes and needs in the process of change (Solomon et al., 2010). Young people usually adopt new technologies and the newest trends first; they pay remarkable attention to image and besides that they have a relatively high purchasing power (Werbner, 2005). For the clothing industry young people capable of paying are interesting. Young people are to a larger extent independent and self-dependent when making purchase decisions for products which they need (Kroeber-Riel et al., 2009). Research in the world shows that young people are financially well supported, spend irrationally, buy their identity and friendship and they take risks (Solomon, 2011). Besides the specific structure of consumption young people also have specific demands and opinions towards individual products and trademarks. The basic function of clothing is to protect the body and to have look aesthetic. But clothing is becoming more and more important for todays youth. Clothing also enables identification. Young people nowadays play a central role in fashion as they are in the period of searching for their own identity which is expressed and created through fashion and clothing. They can also be obsessed with their appearance and needs.

In the article we want to answer two basic research questions: what is the importance for young people aged between 15 and 24 from defined EU countries (Slovenia, Austria and Germany) and the USA regarding factors of purchase and information behaviour when purchasing clothing and what is the opinion of the researched population towards fashion clothing. On the basis of the gained results we want to find intercultural differences in the purchase and information behaviour as well as their opinions towards fashion clothing. Culture is reflected as an important factor of purchase decision making. Intercultural differences in the purchase behaviour of consumers on different continents were discovered in more research (Kwan, 2006).

Received: $7^{\text {th }}$ November 2011; revised: $12^{\text {th }}$. December 2011; accepted $30^{\text {th }}$ December 2011 
Among the stated countries we compared purchase behaviour to find out if it comes down to intercultural differences. To enter the foreign markets in Austria, Germany and the USA and for the optimum functioning of marketing activities in individual foreign markets it is necessary to know the specificities of their consumers. The results of the quantitative research will be useful for multinational corporations that want to conquer the stated markets. Slovenia was chosen for research as the domestic country. Austria and Germany are important commercial partners for Slovenian companies. Germany with a population of approximately 81 million people also presents the biggest market in the EU. There are more than 9 million young people in the researched age (World Population Prospect, 2011). The market of the USA is interesting for the clothing industry because of its absorption capacity. The USA are the most important trading partner of the EU, the third biggest importer of clothing industry products from the EU and therefore interesting for treating the differences between both continents. According to the data of the UN (World Population Prospects, 2011) there are more than 43 million young people aged between 15 and 24 in the USA and they represent an important market segment (Solomon and Rabolt, 2009). In this article we are finding similarities and differences respectively in the purchase decision making of young consumers. The gained results will be useful for companies especially from the point of differentiation of the marketing functioning on individual markets. We decided to choose the stated countries and continents as there has been no comparison of purchase behaviour of young people choosing clothes among the countries yet. The findings will be an important contribution not only from the scientific point of view but also from a practical one.

\section{Factors of purchase and information behaviour}

Studying factors of purchase and information behaviour is important for the clothing industry from the marketing point of view. Knowing the consumers ' marketing needs and understanding their buyers is therefore significant for everybody involved in the production process (Shulz, 2008). Information gained by researching consumers can be used in four areas: marketing mix, segmentation, positioning and differentiation as well as environment analysis and marketing research. Knowing the specific purchase and information behaviour of consumers influences the forming of the marketing mix in companies of the clothing industry. If they want to manufacture commercially successful clothing, experts (designers, marketers and others) have to predict the consumers ' taste as well as to understand its target market and to adjust to it in the elements of the marketing mix.

\subsection{Clothes characteristics and opinions towards fashion clothes}

Knowing the factors of purchase decision-making is important in the process of forming marketing strategies and the market- ing mix for young people's clothes. Numerous authors worked on the factors of purchase decision-making. The consumer's perception of the meaning of different factors of purchase decision-making was measured by numerous researchers in the past (Cassill and Drake, 1987; Zhang et al., 2002), who found 20 characteristics important for the purchase decisionmaking (colour, comfort, durability, care, label, fitting, style, gender accordance, breathable, trademark, country of origin, price, shop's image, the possibility of usage on different occasions, etc.). They used the Likert scale for measuring whereby one meant very unimportant and five very important. Eckman and others (1990) summed up the factors that influence consumers when choosing clothing from their 21 studies and divided them into 35 extrinsic (price, trademark, country of origin, shop's image, wardrobe accordance, politeness of salespeople, guarantee...) and 52 intrinsic (product composition: style, colour, cut, factory, look, fibre content; product look: care, fitting, durability, comfort, safety, colour; quality: structure, physical, producer; gender accordance). In their research study Forney and others (1999) studied thoroughly the meaning of assessment measures for the acceptation of the purchase decision. They found that 21 factors influence the purchase of clothing: colour, design, trademark, price, comfort, fashionableness, durability, quality, cloth fitting, seller obligingness, maintenance simplicity, country of origin, etc. In the research (Kavčič, 2005) Slovenian consumers attributed the biggest meaning to cloth fitting, comfort, design, etc. A lower value is attributed to the fashionableness of clothing. Adult consumers in the USA give the biggest meaning to cloth fitting, price, cut and colour when making decisions regarding clothing purchase (Lifestyle Monitor, 2009a). Many researchers found that prices are the most important factor when purchasing clothing (Iwanow et al., 2005; Joergens, 2006; Fadiga et al., 2005; North et al., 2003; in Hyllegard et al., 2009). Taylor and Cosenza (2002) in their study found that for older girls the most important criteria for choosing clothes are fitting, look, cut, price and colour.

Young people have different opinions towards fashionable clothes. Some believe that fashionable clothes are of bad quality, made from poor material, not functional and uncomfortable, even bad for health because of the cuts and the material. Successful marketers must be aware of the fact that for young consumers, quality is of essential meaning (Solomon et al., 2009). They also have different opinions towards the prices of fashionable clothes. Some are convinced that the clothing industry (producers) in development and production does not take the wishes of young consumers into consideration. By knowing purchase habits of the young population, producers (clothing industry) design, develop, produce and sell fashionable clothes for young people and form marketing strategies that wake the interest of consumers for a definite sort of product (Kotler, 2004).

\subsection{Information sources}

In the decision making process information and consumer information behaviour play an important role. From the mass of information consumers are faced with daily we should choose important information or signals which would enable 
us to make a purchase decision. The meaning of correct, accurate and timely informing has become decisive in all areas of public and private life. Only the informed has the opportunity of sensible decision making and acting (Devetak, 2007). Consumer information behaviour usually starts with the consumers" wish for information and includes a whole range of activities that serve gaining, processing, storing and further passing on of desired information. There are numerous factors which strongly influence young people as consumers. The most important are family, school, peers, purchase experiences, clothing industry, mass media, etc. Consumers often use informal and social sources respectively when looking for information (Goldsmith and Clark, 2008). Consumers receive and look for information about a product at different sources: a salesman at the shop, word-of-mouth communication and from mass media (newspapers and magazines, test announcements, catalogues, etc.) and lately increasingly the Internet (Blyte, 2008; Devetak and Marulc, 2011). More and more goods are sold on the Internet. Salespeople are convinced that goods are sold better and faster on the Internet (Rickman and Cosenza, 2007). The basic commercial information sources when purchasing clothing are: radio advertisements, TV shows and commercials, fashion magazines, catalogue sales of clothing, the Internet, etc. Marketers will have to pay increasingly attention to the Internet. Virtual communities such as MySpace.com, Facebook and Twitter offer forums where consumers can connect with friends and share different information. Consumers can also join a group of interest that is connected with fashion and express their affection for a definite trademark as well as share their opinion with a broader public (Thomas et al., 2007). At first young people attributed a greater meaning to television when purchasing clothing; later research gives advantage to newspapers, friends and sales staff at the shops (Lumpkin and Greenberg, 1982, Lumpkin, 1985; in Yoo-Kyoung, 2009). Morton (2002) finds that young consumers are mistrustful towards mass media and expose wordof-mouth communication. On the basis of research of young girls in the USA display windows are assessed the highest, followed by other people, catalogues, fashion magazines, etc. (Lyfe Stile Monitor, 2009). The most important information sources about clothing in Slovenia are friends and acquaintances, articles in fashion magazines, passers-by on the street, fashion shows on TV (Kavčič, 2005).

\section{Research methodology}

In the empiric part of the article we carried out a quantitative research whose purpose was to find out what meaning is given to individual purchase factors when purchasing clothing by young people from the EU countries (Slovenia, Austria and Germany) and the USA and which information sources they give preference to when making purchase decisions.

\subsection{The sample of the quantitative research}

The sample of the quantitative research, $\mathrm{N}=440$, represents students aged between 15 and 24 from the researched EU countries (Slovenia, Austria and Germany) and the USA.
Because this is an international research which is finding intercultural differences among young people in individual countries and great extensions of geographical areas, the usage of the probability sampling cannot be realized. We limited to the quota sample which enables valid intercultural comparisons and is used in most scientific studies and doctoral dissertations, in which we thoroughly study intercultural differences in the purchase behaviour. In quota sampling we choose the units in a way that the sample structure reflects the structure of the whole population. The quota sample must be in accordance with the structure of the whole population from the point of those variables that essentially influence the data we are estimating (Bregar et al., 2005). The interviewees who took part in the survey are homogenous regarding age and gender and so they are consecutively comparable units. The sample is divided into dependent quotas: gender (definite number of male, definite number of female), country and age. We set the quotas in a way that their structure suits the structure of the population. In the quota sample 220 interviewees were included from individual countries of the EU (121 male and 99 female) and from the USA (113 male and 107 female). The usage of homogenous (above all students) samples with improbability sampling is becoming a frequent practice in intercultural research (Burton et al., 2000; Soares, 2004). In scientific research where we thoroughly study intercultural differences mostly samples of students are used (Forsythe et al., 1999; Taylor and Cosenza, 2002; Schaefer et al., 2009; Zhihong and Zhang, 2011).

\subsection{Research procedure}

The survey was carried out between 15 June 2011 and 15 October 2011 at secondary schools and faculties in Slovenia (Murska Sobota, Maribor, Slovenj Gradec, Celje, Ljubljana, Koper and Novo Mesto), in Austria (Vienna, Graz, Klagenfurt and Salzburg), in Germany (Berlin, Essen, Marburg in Ingolstadt) and in the USA (Boston (Massachusetts), Austin (Texas), Fort Wayne (Indiana) and Berkeley (California). We presume that young people independently decide on clothing and that sampled units in towns where research will take place do not essentially differ from the purchase behaviour of the remaining population in the country. We also presume that information plays an important role and can essentially influence consumers' behaviour, especially in the sense of purchase decision making. In each country the survey was carried out for as long as it lasted to get enough answers from people who provide comparable samples that are balanced regarding the country, gender and age. The survey was required out personally in groups in class. The interviewees themselves answered the questions in the questionnaire in written form with the attendance of an interviewer.

The questionnaire included 37 questions. The main part of the questionnaire included the following areas:

1. Perception of influence of individual information sources on the purchase of clothing,

2. perception of importance of individual factors of purchase decision-making and

3. opinions towards fashion clothing. 
Information sources and factors of purchase decisionmaking when choosing clothing were defined in the questionnaire on the basis of findings of numerous authors in domestic and foreign secondary literature (Eckman et al., 1990; Taylor and Cosenza, 2002; Law, 2002; Forsythe et al., 1999, Kwan, 2006), but at the same time interviewees had the alternative to write an answer which was not predicted among the given ones. Statements that influence opinions in connection with fashionable clothes were formed on the basis of interviews with hundreds of young people at home and abroad. To assess the influence of individual information sources on purchase decisions we used the five-level Likert scale, where grade 1 means no influence at all and grade 5 complete influence. The assessment of the factors of purchase decision-making was also done using the five-level Likert scale, where grade 1 means absolutely unimportant and grade 5 very important. To find out young consumers' opinions towards fashionable clothes we also used the five-level Likart scale of agreement, where grade 1 means I do not agree at all and grade 5, I totally agree. Before starting the survey we tested the questionnaire. When forming the questions we checked the ideas and word choice with the focus group of secondary school students and students from higher educational institutions in Slovenia. Afterwards we discussed the questionnaire with colleagues and experts from the treated field and the field of methodology. Finally we tested the questionnaire by personal surveying on the sample of 40 people ( 20 men and 20 women) aged 15 to 24 from Slovenia, Austria, Germany and the USA. For the performance of the research in Austria, Germany and the USA we translated the questionnaire into Englsih and German. Based on the testing of the questionnaire there were some changes made to it. To assure good measure quality we assessed the reliability of the measure instrument by Cronbach's alpha coefficient of reliability. The input and analytical processing of data was carried out by the statistics software IBM SPSS Statistics 19. Data processing shows descriptive statistics, t-test and basic data comparisons.
On the basis of defined research questions and in accordance with the research goals we set basic research hypothesis:

Hypothesis 1: Between the groups of young people in the countries of the EU and the USA there are statistically important differences in assessing individual factors that influence the purchase of clothing.

Hypothesis 2: Groups of young people from the EU and the USA differ importantly in the perception of the influence of individual information sources on the purchase of clothing.

Hypothesis 3: Opinions of young people towards fashionable clothes differ importantly in reference to the continent (EU, USA).

\subsection{Main results of the empirical study}

In continuation of the article we present the most important findings of the research.

\subsubsection{Testing the hypothesis}

The set alternative hypothesis $\mathrm{H} 1$ is tested with the $\mathrm{T}$ Test (Independent Samples T Test procedure). The hypothesis is accepted if the characteristics level is $\mathrm{P}<(\alpha=0,05)$, which means that the difference is characteristic. In case that the stated conditions are met only with individual factors, the alternative hypothesis is partly accepted with the declaration of the factor. The results of the T Test are shown in table 1 .

The results of the $\mathrm{T}$ test show that the alternative hypothesis H1 is partly accepted. The differences between young people in the countries of the EU and the USA are characteristic for the following factors of purchase decision-making: colour, design, trademark, fashionableness, price, comfort, maintenance simplicity and country of origin. For the stated factors the alternative hypothesis is accepted on the basis of the sample data.

Table 1: T Test of differences between arithmetic means of grade of two groups

\begin{tabular}{|l|c|c|c|}
\hline & t & df & Sig. (2-tailed) \\
\hline Colour & 2,783 & 438 &, 006 \\
\hline Design/fashion & 9,259 & 438 &, 000 \\
\hline Trademark & 4,028 & 438 &, 000 \\
\hline Quality &, 356 & 438 &, 722 \\
\hline Fashionableness & 3,623 & 438 &, 000 \\
\hline Price & $-6,484$ & 438 &, 000 \\
\hline Fitting clothes &, 871 & 438 &, 384 \\
\hline Comfort & $-2,394$ & 438 &, 017 \\
\hline Maintenance simplicity & $-5,055$ & 438 &, 000 \\
\hline Seller obligingness &,- 346 & 438 &, 730 \\
\hline Country of origin & 4,288 & 438 &, 000 \\
\hline
\end{tabular}

Source: Own research 2011 
Table 2: T Test of differences between arithmetic means of grade of two groups

\begin{tabular}{|l|c|c|c|}
\hline & $\mathbf{t}$ & df & Sig. (2-tailed) \\
\hline Radio advertisement & 2,566 & 438 &, 011 \\
\hline Ads and shows on TV &, 912 & 438 &, 362 \\
\hline Ads and articles in newspapers & 6,220 & 438 &, 000 \\
\hline Fashion magazines & 4,595 & 438 &, 000 \\
\hline Catalogue selling & 4,852 & 438 &, 000 \\
\hline Showroom advertising & 6,893 & 438 &, 000 \\
\hline Direct mail & 6,690 & 438 &, 000 \\
\hline Friends and acquaintances &,- 224 & 438 &, 823 \\
\hline Clothes seller & $-1,870$ & 438 &, 062 \\
\hline Hoardings on the streets & 6,699 & 438 &, 000 \\
\hline Websites on the Internet &, 435 & 438 &, 664 \\
\hline Facebook, MySpace, Twitter &,- 204 & 438 &, 838 \\
\hline
\end{tabular}

Source: Own research 2011

Table 3: T Test of differences between arithmetic means of grade of two groups

\begin{tabular}{|c|c|c|c|}
\hline & $\mathbf{t}$ & df & Sig. (2-tailed) \\
\hline Fashion clothes producers pay regard to wishes of young people. & 2,941 & 438 & ,003 \\
\hline Fashion clothes are of bad quality (poorer material, harder maintenance, ...). & 1,034 & 438 & ,302 \\
\hline Fashion clothes are not functional and uncomfortable. & 2,082 & 438 & 038 \\
\hline $\begin{array}{l}\text { Fashion clothes are harmful for health (wide neck, short vests, light materials in } \\
\text { winter, ...). }\end{array}$ & 2,415 & 438 & ,016 \\
\hline Fashion for young people changes too fast. & 3,029 & 438 & 003 \\
\hline Market prices for fashion clothes are too high. & 6,917 & 438 & 000 \\
\hline I can use fashion clothes for many seasons. & 4,537 & 438 & ,000 \\
\hline Fashion clothes improve my self-image. & 1,813 & 438 & 071 \\
\hline Fashion clothes attract attention with people. & ,122 & 438 & ,903 \\
\hline
\end{tabular}

Source: Own research 2011

For the factors of purchase decision-making: quality, clothes fitting and seller obligingness the results of the T Test do not show the characteristic difference. On the basis of the sample data for these sources the Null hypothesis is accepted as young people on both continents do not differ in the assessment of the factors that influence the purchase of clothing.

The alternative hypothesis $\mathrm{H} 2$ is also tested with the $\mathrm{T}$ Test (Independent Samples T Test procedure).

The results of the T Test show that the alternative hypothesis $\mathrm{H} 2$ is partly accepted. Differences between young people in the countries of the EU and the USA are characteristic for the following information sources: radio advertisements, advertisements and articles in newspapers, fashion maga- zines, catalogue sales, showroom advertising, direct mail and hoardings on the streets. For the stated sources the alternative hypothesis is partly accepted on the basis of the sample data.

For the information sources: TV commercials and shows, friends and acquaintances, clothes sellers, Internet websites and social networks (Facebook, MySpice, Twitter) the results of the $\mathrm{T}$ test do not show characteristic differences. On the basis of the sample data for these sources the Null hypothesis is accepted as young people on both continents do not differ in the assessment of information sources that influence the purchase of clothing.

The set alternative hypothesis H3: Opinions of young people towards fashionable clothes importantly differ in 
reference to the continent (EU, USA) is tested by the T Test (Independent Samples T Test procedure). The hypothesis is accepted if the characteristics level is $\mathrm{P}<(\alpha=0,05)$, which means that the difference is characteristic. In case that the stated conditions are met only with individual opinions, the alternative hypothesis is partly accepted with the declaration of the opinion. The results of the T Test are shown in table 3 .

The results of the T Test show that the alternative hypothesis H3 is partly accepted. Differences between young people in the countries of the EU and the USA are characteristic for the following statements: »fashion clothes producers pay regard to wishes of young people «, »fashion clothes are not functional and uncomfortable «, »fashion clothes are harmful for health «, »fashion for young people changes too fast «, »market prices for fashion clothes are too high « and »I can use fashion clothes for many seasons «. For the stated opinions the alternative hypothesis is partly accepted on the basis of the sample data.

For the statements »fashion clothes are of bad quality«, »fashion clothes attract attention with people « and »fashion clothes improve my self-image « the results of the T Test do not show the characteristic difference. On the basis of the sample data for these statements the Null hypothesis is accepted as young people on both continents do not differ in the assessment of opinions towards fashion clothes.

\subsubsection{Data analysis and discussion}

The comparison of both groups shows that there are intercultural differences in the meaning that is given to the factors of purchase decision making by young people from countries in the EU and the USA. We are finding that the biggest differences in value are in the following factors: colour, design, trademark, fashionableness, price, comfort and maintenance simplicity. Both groups attribute the least meaning to the country of origin and the seller obligingness. Young people from the USA assessed the following factors essentially lower: design, trademark, fashionableness and country of origin whereas they assessed the following factors essentially higher: price, clothes fitting and simplicity of maintenance. In table 4 the descriptive statistics of the grades of purchase decisionmaking factors by continent are shown.

Young people from the EU on average assessed the following factors the highest:

Table 4: Descriptive statistics of grades of purchase decision-making factors by continent

\begin{tabular}{|c|c|c|c|c|}
\hline & Continent & $\mathbf{N}$ & Mean & Std. Deviation \\
\hline \multirow{2}{*}{ Colour } & EU & 220 & 4,30 & ,969 \\
\hline & USA & 220 & 4,04 & ,983 \\
\hline \multirow{2}{*}{ Design/fashion } & EU & 220 & 4,48 &, 857 \\
\hline & USA & 220 & 3,49 & 1,336 \\
\hline \multirow{2}{*}{ Trademark } & EU & 220 & 2,87 & 1,247 \\
\hline & USA & 220 & 2,39 & 1,286 \\
\hline \multirow{2}{*}{ Quality } & $\mathrm{EU}$ & 220 & 4,08 & ,913 \\
\hline & USA & 220 & 4,05 & ,961 \\
\hline \multirow{2}{*}{ Fashionableness } & $\mathrm{EU}$ & 220 & 3,74 & 1,232 \\
\hline & USA & 220 & 3,32 & 1,216 \\
\hline \multirow{2}{*}{ Price } & $\mathrm{EU}$ & 220 & 3,90 & 1,085 \\
\hline & USA & 220 & 4,50 &, 857 \\
\hline \multirow{2}{*}{ Fitting clothes } & $\mathrm{EU}$ & 220 & 4,55 & ,840 \\
\hline & USA & 220 & 4,48 &, 802 \\
\hline \multirow{2}{*}{ Comfort } & EU & 220 & 4,07 & 1,018 \\
\hline & USA & 220 & 4,29 &, 890 \\
\hline \multirow{2}{*}{ Maintenance simplicity } & EU & 220 & 3,00 & 1,170 \\
\hline & USA & 220 & 3,55 & 1,111 \\
\hline \multirow{2}{*}{ Seller obligingness } & $\mathrm{EU}$ & 220 & 2,24 & 1,279 \\
\hline & USA & 220 & 2,28 & 1,202 \\
\hline \multirow[t]{2}{*}{ Country of origin } & $\mathrm{EU}$ & 220 & 2,04 & 1,221 \\
\hline & USA & 220 & 1,57 & 1,064 \\
\hline
\end{tabular}

Source: Own research 2011 
- clothes fitting $(4,55)$,

- design $(4,48)$,

- $\operatorname{colour}(4,30)$,

- quality $(4,08)$ and

- comfort $(4,07)$.

Young consumers from the USA attribute the biggest meaning in purchase decision making when choosing clothes to the following factors:

- price $(4,50)$,

- clothes fitting $(4,48)$,

- comfort $(4,29)$,

- quality $(4,05)$ and

- $\operatorname{colour}(4,04)$.

The most important difference shows in the price which is the most important factor of purchase decision making in the USA whereas in the EU it takes the last position. Also design does not have an important influence for young people in the
USA which is, on the other hand, highly preferred by young people in the EU (second most important factor).

In table 5 the descriptive statistics of the grades for information sources by the continent is shown. Among young people in the EU and the USA we are finding differences in the assessment of information sources influence on purchase decision making when choosing clothes. The comparison of young people in the EU and in the USA shows that there are characteristic differences in the assessment of sources.

The results of checking hypothesis 2 show typical value differences for the following information sources: radio advertisements, advertisements and articles in newspapers, fashion magazines, catalogue sales, showroom advertising, direct mail and hoardings on the streets. All the stated information sources are assessed essentially higher by young people from the EU. Both groups attribute the lowest influence on purchase decisions to the sources: radio advertisements and social networks (Facebook, MySpice, Twitter). Young people from the USA assessed the following sources essentially lower: radio adver-

Table 5: Descriptive statistics of the grades for information sources by continent

\begin{tabular}{|c|c|c|c|c|}
\hline & Continent & $\mathbf{N}$ & Mean & Std. Deviation \\
\hline \multirow{2}{*}{ Radio advertisements } & EU & 220 & 1,41 & ,914 \\
\hline & ZDA & 220 & 1,22 & ,618 \\
\hline \multirow{2}{*}{ TV ads and shows } & EU & 220 & 2,34 & 1,156 \\
\hline & ZDA & 220 & 2,24 & 1,197 \\
\hline \multirow{2}{*}{ Advertisements and articles in newspapers } & EU & 220 & 2,52 & 1,168 \\
\hline & ZDA & 220 & 1,83 & 1,063 \\
\hline \multirow{2}{*}{ Fashion magazines } & EU & 220 & 2,70 & 1,140 \\
\hline & ZDA & 220 & 2,12 & 1,322 \\
\hline \multirow{2}{*}{ Catalogue sales } & $\mathrm{EU}$ & 220 & 2,69 & 1,189 \\
\hline & USA & 220 & 2,08 & 1,287 \\
\hline \multirow{2}{*}{ Showroom advertising } & $\mathrm{EU}$ & 220 & 3,21 & 1,061 \\
\hline & USA & 220 & 2,35 & 1,398 \\
\hline \multirow{2}{*}{ Direct mail } & EU & 220 & 2,40 & 1,237 \\
\hline & USA & 220 & 1,64 & 1,091 \\
\hline \multirow{2}{*}{ Friends and acquaintances } & $\mathrm{EU}$ & 220 & 3,30 & 1,169 \\
\hline & USA & 220 & 3,32 & 1,296 \\
\hline \multirow{2}{*}{ Clothes sellers } & EU & 220 & 2,31 & 1,121 \\
\hline & USA & 220 & 2,53 & 1,248 \\
\hline \multirow{2}{*}{ Hoardings on the street } & EU & 220 & 2,18 & 1,044 \\
\hline & USA & 220 & 1,54 & ,898 \\
\hline \multirow{2}{*}{ Internet websites } & EU & 220 & 2,70 & 1,245 \\
\hline & USA & 220 & 2,64 & 1,450 \\
\hline \multirow[t]{2}{*}{ Facebook, MySpace, Twitter } & EU & 220 & 1,73 & 1,095 \\
\hline & USA & 220 & 1,75 & 1,136 \\
\hline
\end{tabular}

Source: Own research 2011 
tisements, advertisements and articles in newspapers, fashion magazines, catalogue sales, direct mail and hoardings on the streets whereas they assessed the following sources essentially higher: clothes sellers and showroom advertising.

Young people from Europe assess the following factors the highest:

- friends and acqaintances $(3,30)$,

- showroom advertising $(3,21)$,

- Internet websites (2,70),

- fashion magazines $(2,70)$ and

- catalogue sales $(2,69)$.

The lowest assessed were the sources: radio advertisements $(1,41)$ and social networks $(1,73)$.

The following sources on young people in the USA in purchase decision-making when choosing clothes have the biggest influence:

- friends and acqaintances $(3,32)$,

- Internet websites $(2,64)$,

- clothes sellers $(2,53)$,

- showroom advertising $(2,35)$ and

- TV ads and shows $(2,24)$.

The following sources have the least influence: radio advertisements $(1,22)$ and hoardings on the street $(1,54)$.

The comparison of both groups in table 5 also shows that showroom advertising have a bigger influence on young people in the EU when choosing clothes whereas they do not have a noticeable influence on young people in the USA. Among countries of the EU there are no big differences. In all countries of the EU the biggest influences are friends and acquaintances, showroom advertising and Internet websites. In Slovenia direct mailing about clothing, which is placed lower in the other countries, is an important source of information. In Austria and Germany young people value catalogue sales highly.

By checking hypothesis 3 we found characteristic differences among young people in the EU and the USA for the following statements: »fashion clothes producers pay regard to wishes of young people«, »fashion clothes are not functional and uncomfortable «, »fashion clothes are harmful for health «, »fashion for young people changes too fast «, »market prices for fashion clothes are too high «, »I can use fashion clothes for many seasons « and »fashion clothes improve my self-image «. Table 6 shows that young people in the EU express a higher level of agreement with the following statements: »fashion clothes producers pay regard to wishes of young people «, »fashion clothes are harmful for health «, »I can use fashion clothes for many seasons « and »fashion clothes improve my self-image « whereas young people in the USA assess the following statements higher: »fashion clothes are not functional and uncomfortable «, »fashion for young people changes too fast $«$ and »market prices for fashion clothes are too high $«$.

Table 6: Descriptive statistics of grades of opinions towards fashion clothes by continent

\begin{tabular}{|c|c|c|c|c|}
\hline & Continent & $\mathbf{N}$ & Mean & Std. Deviation \\
\hline \multirow[t]{2}{*}{ Fashion clothes producers pay regard to wishes of young people. } & EU & 220 & 3,35 & ,993 \\
\hline & USA & 220 & 3,05 & 1,111 \\
\hline \multirow{2}{*}{$\begin{array}{l}\text { Fashion clothes are of bad quality (poorer material, harder mainte- } \\
\text { nance, ...). }\end{array}$} & EU & 220 & 2,52 & 1,040 \\
\hline & USA & 220 & 2,62 & 1,081 \\
\hline \multirow{2}{*}{ Fashion clothes are not functional and uncomfortable. } & EU & 220 & 2,52 & 1,116 \\
\hline & USA & 220 & 2,74 & 1,127 \\
\hline \multirow{2}{*}{$\begin{array}{l}\text { Fashion clothes are harmful for health (wide neck, short vests, light } \\
\text { materials in winter, ...). }\end{array}$} & $\mathrm{EU}$ & 220 & 2,22 & 1,193 \\
\hline & USA & 220 & 1,96 & 1,011 \\
\hline \multirow{2}{*}{ Fashion for young people changes too fast. } & EU & 220 & 3,10 & 1,165 \\
\hline & USA & 220 & 3,45 & 1,258 \\
\hline \multirow{2}{*}{ Market prices for fashion clothes are too high. } & EU & 220 & 3,63 & 1,109 \\
\hline & USA & 220 & 4,30 & ,923 \\
\hline \multirow{2}{*}{ I can use fashion clothes for many seasons. } & EU & 220 & 3,60 & 1,165 \\
\hline & USA & 220 & 3,08 & 1,210 \\
\hline \multirow{2}{*}{ Fashion clothes improve my self-image. } & EU & 220 & 3,12 & 1,208 \\
\hline & USA & 220 & 2,90 & 1,365 \\
\hline \multirow{2}{*}{ Fashion clothes attract attention with people. } & EU & 220 & 3,45 & 1,144 \\
\hline & USA & 220 & 3,44 & 1,198 \\
\hline
\end{tabular}

Source: Own research 2011 


\section{Summary and conclusions}

With quantitative research we found intercultural differences in purchase and information behaviour as well as opinions towards fashion clothes. Many researchers claim that young people all over the world have similar tendencies towards products and that there is a general trend in the sense of unity in global economy. According to Friedman (2007) and on the basis of the findings of our research, cultural differences still exist. Cultural traditions are deeply rooted in individuals' values. A study that would show differences in purchase behaviour in choosing clothes among young consumers in the countries of the EU and the USA has not been done yet therefore the findings of our research are so much more important.

Considering the found intercultural differences in the researched factors of purchase and information behaviour as well as the opinions towards fashion clothes, the use of differentiation strategy in the global market is reasonable. Therefore we propose to companies that operate with their clothing for young people on the markets of the EU and the USA to use the following unified media on both continents: clothes sellers in Internet websites. Only in the EU markets we propose to pay greater emphasis on advertisements in fashion magazines and catalogue sales when developing a marketing communication policy whereas in the US market TV commercials and shows have a great influence on the purchase decision. From the point of advertising policy we also propose to companies to think about the meaning of word of mouth communication (friends and acquaintances) and to take advantage of modern technology (social networks, Internet websites) for spreading positive information about a product and company. For young people in the researched countries also Internet websites, which give consumers visual and other information about clothes, fashion and trends in a simple and accessible way, are important. Regarding the factors of purchase decision making that are connected to the clothes characteristics the biggest deviations between the continents are in the price, which is most important for young people in the USA and the design, whose importance for a purchase decision was highly assessed by young people in the EU. When developing a marketing strategy for both markets the knowledge of differences in opinions is important. Young people in the EU express a higher level of agreement with the following opinions: »fashion clothes producers pay regard to wishes of young people «, »fashion clothes are harmful for health «, »I can use fashion clothes for many seasons « and »fashion clothes improve my self-image «, whereas young people in the USA assess the following opinions higher: »fashion clothes are not functional and uncomfortable«, »fashion for young people changes too fast « and »market prices for fashion clothes are too high $\ll$.

The findings have practical value for the biggest clothes producers for young people such as Inditex, H\&M, C\&A, S. Oliver, New Yorker and others, which supply the global markets with their products.

\section{References}

Blythe, J. (2008). Consumer Behavior, Thomson Learning, London. Bregar, L., Ograjenšek, I. \& Bavdaž, M. (2005). Metode raziskovalnega dela za ekonomiste: izbrane teme [Research Methodology for Economists: Selected Topics], University of Ljubljana, Faculty of Economics.

Cassill, L. N. \& Drake, F. M. (1987). Apparel selection criteria related to female consumers lifestyle, Clothing and Textile Research Journal, 6 (1): 20-28. DOI:10.1177/0887302X8700600104

Devetak, G. (2007). Marketing management [Marketing Management], University of Primorska, Faculty of Management.

Devetak, G. \& Marulc, E. (2011). Assessing the importance of sustainable development factors in dental tourism, In People and sustainable organization, Ed. T. Kern and V. Rajkovič, pp- 312336. Frankfurt am Main: Peter Lang.

Eckman, M., Damhorst, M. L. \& Kadolph, S. J. (1990). Toward a model of the in-store purchase decision process: consumer use of criteria for evaluating womens apparel, Clothing and Textiles Journal, 8 (2): 13-22. DOI: 10.1177/0887302X9000800202

Forsythe, S., Kim, J. O. \& Petee, T. (1999). Product cue usage in two Asian markets: a cross-cultural comaparison, Asia Pacific Journal of Management, 16 (2): 275-292. DOI: 10.1023/A:1015447211534

Fowler, J. F. (2002). Survey Research Method. Sage publications.

Friedman, T. L. (2007). The World Is Flat: A Brief History of the Twenty-First Century, Picador, New York.

Goldsmith, R. E. \& Clark, R. A. (2008). An analysis of factors affecting fashion opinion leadership and fashion opinion seeking, Journal of Fashion Marketing and Management, 12 (3): 308322. DOI: $10.1108 / 13612020810889272$

Hyllegard, K., Ogle, J. \& Yan, R. N. (2011). The impact of advertising message strategy - fair labour v. sexual appeal - upon Gen Y consumers intent to patronize an apparel retailer, Journal of Fashion Marketing and Management, 13 (1):109-127. DOI: $10.1108 / 13612020910939914$

Kavčič, A. (2005), Odnos potrošnikov do nakupa modnih oblačilnih znamk [Consumer attitudes towards the purchase fashion apparel brand], Master's thesis, University of Ljubljana, Faculty of Economics.

Kotler, P. (2004). Management trženja [Marketing Management], GV založba, Ljubljana.

Kroeber-Riel, W., Weinberg, W. P. \& Gröpel-Klein, A. (2009), Konsumenten-verhalten, Verlag Franz Vahlen, München.

Kwan, C. Y. (2006). An investigation on the factors affecting young Chinese consumers' decision-making behaviour towards casual wear purchase, Ph.D., Hong Kong Polytechnic University, available from: http://splet03.izum.si:2054/pqdweb?did=128864942 $1 \&$ sid $=5 \&$ Fmt $=2 \&$ clientId $=72300 \&$ RQT $=309 \&$ VName $=P Q D$ (4. 5. 2011).

Law, K. M. (2002). The influences of fashion change on the apparelbuying of young generation in Hong Kong, The Hong Kong Polytechnic University, available from: http://splet03.izum. si:2054/pqdweb?index $=0 \&$ sid $=2 \&$ srchmode $=1 \&$ vinst=PROD $\&$ $\mathrm{fmt}=6 \&$ startpage $=1 \&$ clientid $=72300 \&$ vname $=P Q D \& R Q T=30$ $9 \&$ did $=726483561 \&$ scaling $=$ FULL\&ts $=1304485252 \&$ vtype $=P$ QD\&rqt=309\&TS=1304485262\&clientId=72300 (4. 5. 2011).

Lifestyle Monitor. (2009). Fit, Price, Style and Color are the Top Apparel Purchase Drivers for Consumers, available from: http:// lifestylemonitor.cottoninc.com/LSM-Fast-Facts/Consumer-TopApparel-Purchase-Drivers/ (14. 12. 2010).

Lifestyle Monitor. (2009a). Consumers Influenced By Celebrity In Good Times And Bad, available from: http://lifestylemonitor. cottoninc.com/lsmweekly/lsmweeklyarticles/?articleID=644\&p revArticle $=2 \&$ nextArticle $=4$ (14. 12. 2010).

Lumpkin, J. R. (1985). Shopping orientation segmentation of the elderly consumer, Journal of the Academy of Marketing Science. Spring: 271-289.

Morton, L. P. (2002). Targeting generation Y, Public Relations Quartely, 47 (2): 46-53. 
Rickman, T. A. \& Cosenza, R. M. (2007). The changing digital dynamics of multichannel marketing: The feasibility of the weblog: text mining approach for fast fashion trending, Journal of Fashion Marketing and Management, 11 (4): 604-621. DOI: 10.1108/13612020710824634

Schaefer, A. D., Parker, S. \& Hermans, C. M. (2009). Information source usage in teen apparel purchases: China, Japan and the United States, Journal of Fashion Marketing and Management, 13 (4): 541-552. DOI: 10.1007/s10495-010-0456-1

Shulz, S. (2008). Our Lady Hates Viscose: The Role of the Customer Image in High Street Fashion Production, Cultural Sociology, 2 (3): 385 - 405. DOI: 10.1177/1749975508095618

Solomon, M. R. (2011). Consumer Behavior: Buying, having and Being, Pearson Education, New Jersey.

Solomon, M., Bamossy, G., Askegaard, S. \& Hogg, K. M. (2010). Consumer behavior: a European Perspectiv, Pearson Education, Harlow.

Solomon, M. R. \& Rabolt, N. J. (2009). Consumer Behavior: In fashion, Prentice Hall, New Jersey.

Taylor, S. L. \& Cosenza, R. M. (2002). Profiling later aged female teens: male shopping behaviour and clothing choice, Journal of Consumer Marketing, 19 (5): 393-408. DOI: 10.1108/07363760210437623

Thomas, B. J., Peters, C. O. \& Tolson, H. (2007). An exploratory investigation of the virtual Community MySpace.com: What are consumers saying about fashion?, Journal of Fashion Marketing and Management, 11 (4): 587- 603.

Werbner, D. (2005). Youth marketing; The billion dollar quest. Ad Media, available from: http://findarticles.com/p/articles/ mi_qn6203/is_20051219/ai_n24913407/?tag=content;col1 (11. 12. 2010).

World Population Prospects: The 2010 Revision. (2011). United Nations. available from: http://esa.un.org/wpp/Excel-Data/population.htm (11. 9. 2011).
Zhang, Z., Li, Y., Gong, C. \& Wu, H. (2002). Casual wear product attributes: A Chinese consumer`s perspective, Journal of Fashion Marketing and Management, 6 (1): 53-62. DOI: 10.1108/13612020210422464

Zhihong, G. \& Zhang, H. (2011). A comparative study of Chinese and US consumer's attitudes toward advertising regulation, Asia Pacific Journal of Marketing and Logistics, 23 (1): 72-90. DOI: 10.1108/13555851111100003

Yoo-Kyoung, S. (2009). Fashion promotions in the Hispanic market, International Journal of Retail \& Distribution Management, 37 (2):161-181. DOI: 10.1108/09590550910934290

Beno Klemenčič is director at the Business School Murska Sobota and lecturer of Marketing at the Faculty of Commercial and Business Sciences. At the Faculty of Commercial and Business Sciences is finalizing PhD Study in the field of consumer behavior and marketing. He is a member of the Expert Council of the Republic of Slovenia for Vocational and Technical Education.

Gabrijel Devetak is an associate professor of Marketing at the Faculty of Commercial and Business Sciences. His research includes the fields of innovation and marketing. He has published over 1100 bibliographic units.

Darko Števančec is a lecturer at the Business School Murska Sobota and at the Gea College - Faculty of Entrepreneurship. His research work includes several articles and contributions in the field of marketing and business communication and psychology of personality. He has published more than 200 bibliographic units. 